\title{
A Case of latrogenic Ureter Injury: Recent Diagnostic and Treatment Methods
}

\section{Bir Olgu Esliğinde Iyatrojenik Üreter Yaralanmaları Güncel Tanı ve Tedavi Yöntemleri}

\author{
Batuhan Ergani, Hakan Türk, Cemal Selçuk İşoğlu, Mustafa Karabıçak, Ferruh Zorlu
}

Tepecik Training and Research Hospital, Clinic of Urology, İmir, Turkey

\begin{abstract}
The ureters are rarely exposed to trauma. Ureteral injuries are generally in the form of iatrogenic, blunt injuries, and rarely penetrating injuries. latrogenic injuries often occur during surgical procedures. They do not present with specific findings and symptoms, therefore, they have lateonset symptoms. Imaging modalities of choice are usually intravenous pyelography and computed tomography. Treatment is tailored to the location of the trauma.
\end{abstract}

Keywords

Ureter, trauma, iatrogenic ureteral injury, duplicated ureter

\section{ÖZ}

Üreterler nadiren travmaya maruz kalırlar. Üreter yaralanmaları iyatrojenik, künt travmalar ve nadiren penetran yaralanma şeklindedir. İyatrojenik yaralanmalar genellikle cerrahi işlemler ile birlikte olur. Üreter yaralanmalarının spesifik bulgu ve semptomları yoktur. Bu nedenle geç belirti vermektedir. Görüntüleme yöntemi olarak sıklıkla intravenöz pyelografi ve bilgisayarlı tomografiden yararlanılır. Tedavi, travmanın lokalizasyonuna göre belirlenir.

Anahtar Kelimeler

Üreter, travma, iyatrojenik yaralanma, çift üreter

\section{Introduction}

Ureteral traumas are rare representing almost $1-2.5 \%$ of all urogenital system injuries $(1,2)$. Percent of seventy-five ureteral injuries are iatrogenic, 18\% are blunt traumas and 7\% penetrating injuries (3). latrogenic injuries are generally reported to be caused by endourological interventions (42\%), gynecological (34\%) and intra-abdominal surgeries (24\%) (4). latrogenic ureteral injuries do not present with specific findings and symptoms, often with delayed diagnosis and only $1 / 3$ are recognized during surgery (5). This study presents a case of ureteral injury during surgery and discusses the diagnosis and treatment procedures.

\section{Case Presentation}

A 30-years old female patient was admitted to our emergency department with the complaints of extensive abdominal pain, bloating and belching. Her history revealed that she underwent total abdominal hysterectomy + bilateral salpingo-oophorectomy for myoma uteri in another center about 20 days ago. Three days after surgery, she underwent percutaneous nephrostomy for left sided hydronephrosis in a different center that she was referred to with the complaint of abdominal pain. Her physical exam revealed findings of hard abdomen with rebound tenderness. Laboratory workup indicated anemia (hemoglobin=10.1 gr/dl), leukocytosis (white blood cell=15200) and thrombocytosis (platelet $=520$ thousand). Antegrade pyelography showed partial filling of the ureter with opaque substance with the contrast matter not reaching the distal portion (Figure 1). The patient was admitted to the hospital upon computed tomography (CT) results indicating collection to the superior of the bladder (Figure 2).

The patient was taken to operation following preoperative preparations. During the operation, the left ureter was found to be sutured and excised at around $5 \mathrm{~cm}$ to the distal. During dissection, it was also noted that the patient had duplicated collective system (Figure 3). Ureteroureterostomy was performed after removal of the necrotized portion of the distal end of the excised ureter following enteroanastomosis lateral to the other ureter. An ureteral stent was placed to the injured ureter and the procedure was completed. Drain was taken off on post-op day 15. The stent was removed based on her $\mathrm{CT}$ findings in the first month showing no signs of leak (Figure 4). The patient is in her $6^{\text {th }}$ post-op month and does not have any complaint.

\section{Correspondence}

Hakan Türk MD, Tepecik Training and Research Hospital, Clinic of Urology, İzmir, Turkey

Phone: +90 2323244543 E-mail: hkntrk000@hotmail.com Received: 03.07.2015 Accepted: 03.07.2015 


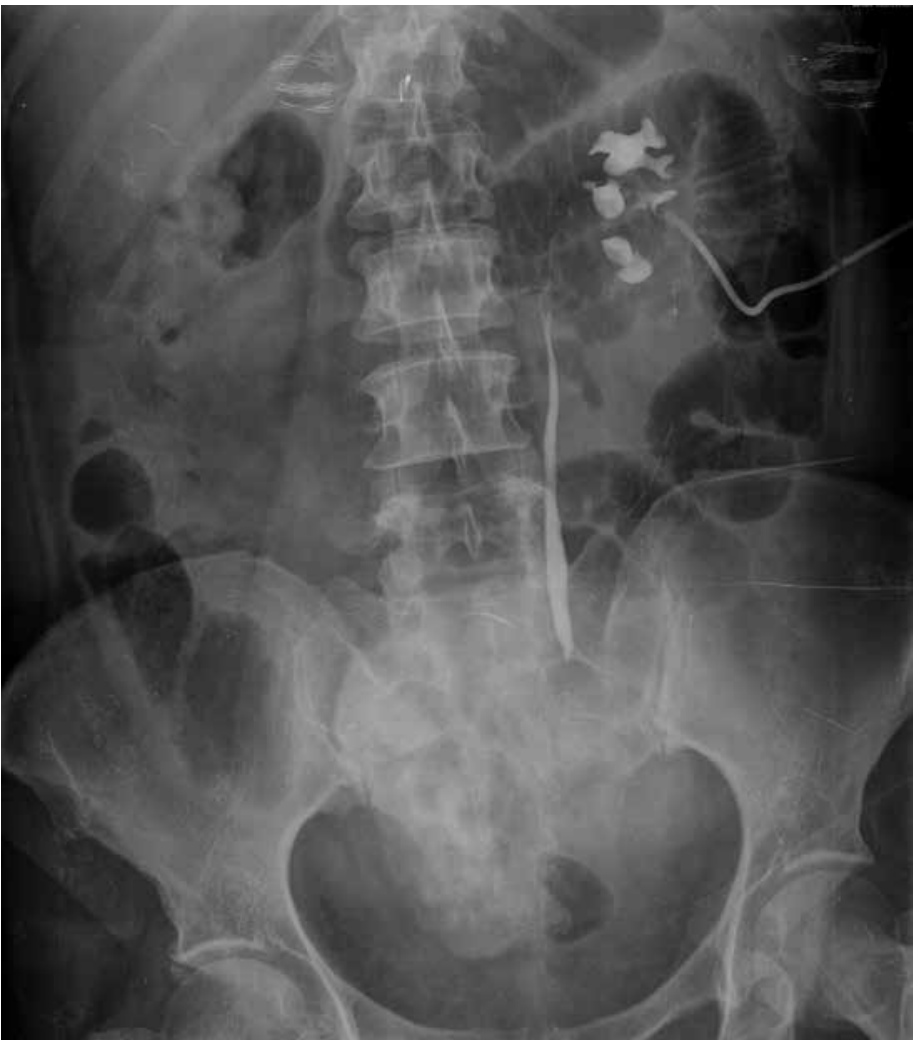

Figure 1. Contrast agent passage through distal ureter was not mentioned by preop antegrade pyelography

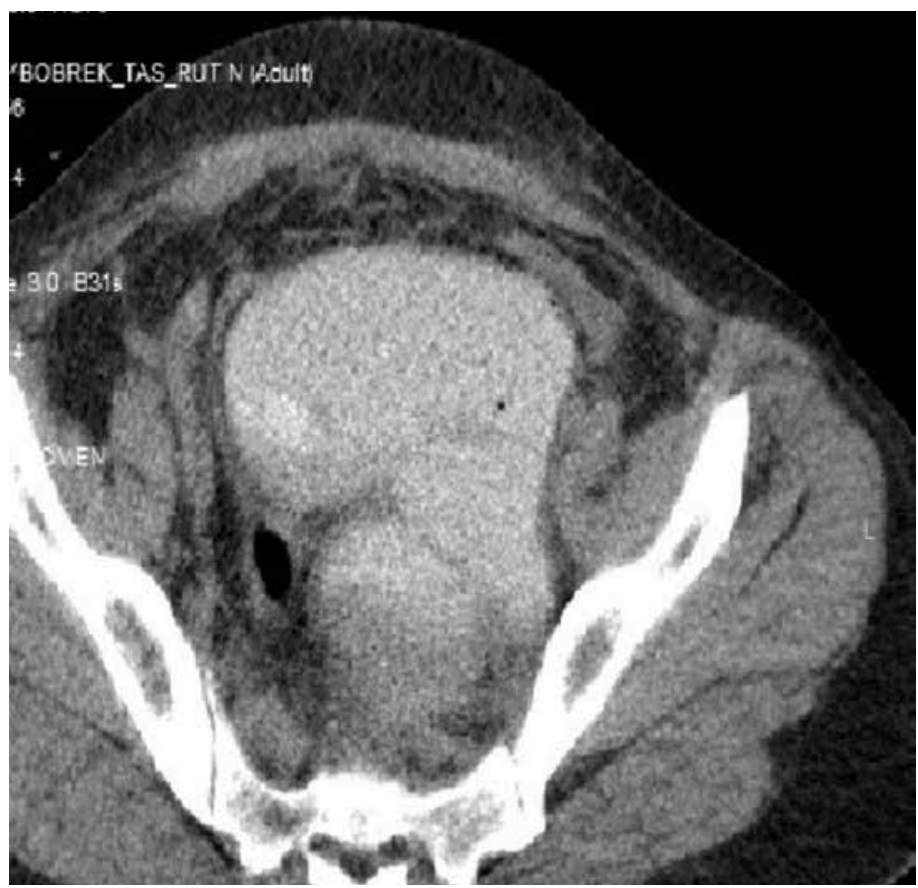

Figure 2. Urinoma formation at the superior part of bladder by computered tomography

\section{Discussion}

Ureter anatomy, supply network and adjacencies should be wellrecognized to avoid ureteral injuries. The ureters are in close adjacency to female genital organs and are threatened during liberation. The

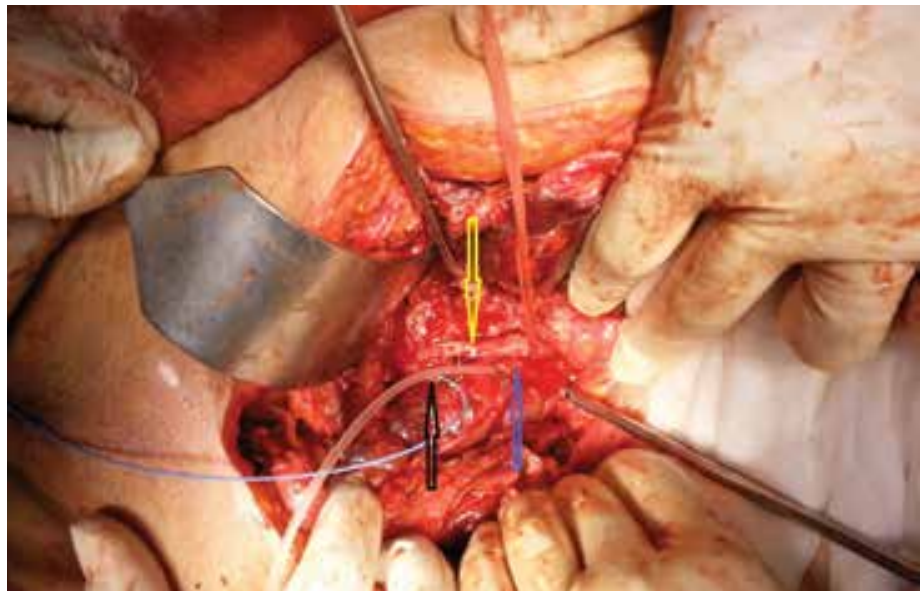

Figure 3. Patient had a duplex collecting system yellow sign healthy ureter blue sign proximal part of the injured ureter black sign distal part of the injured ureter

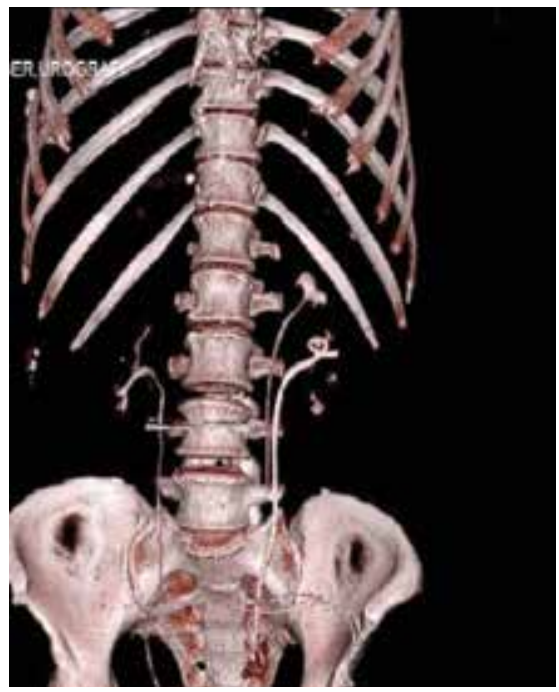

Figure 4. After 1 month computed tomography urography there is no urine leakage

most frequently injured portion of the ureters is the distal parts, as in our case $(4,6)$.

The most common findings of ureteral injuries are side pain and tenderness, hematuria, oliguria, anuria, delayed recovery or increased fluid discharge from drains (for post-op patients), and vaginal fluid leak when the cervical stump remains open. Urinary peritonitis is a chemical peritonitis mostly presenting with extensive abdominal pain, distention and ileus (7). It is sometimes confined by being surrounded with a leaking fibrous capsule to the retroperitoneum causing urinoma (8). Urinoma may get infected and may cause sepsis and electrolyte imbalance.

Radiologic diagnostic tools are ultrasonography (USG), CT or intravenous pyelography in case of an injury. If the ureteral orifices are visible on cystoscopy, presence of urinary flow therein may indicate at least absence of obstruction yet cannot exclude other types of injuries. Outflow of blood or air (in laparoscopic operations) from the orifice during cystoscopy are indirect findings of injury (9). If postop ureteral injury is suspected, urinomas, abscess formations and hydronephrosis may be detected by USG and/or contrast-enhanced $\mathrm{CT}$, whereas $\mathrm{CT}$ urography may contribute to localization of the injury. 
In the order of frequency, the most common locations for ureteral injuries are distal, middle and proximal parts of the ureter $(4,6)$. General principles applicable to organ injuries also apply to ureteral injuries. There are various treatment options depending on the type of ureteral injuries. In minor injuries (clamp crush, needle injuries, etc.), conservative treatment may be applied unless there is suspicion of ureter vitality and leak, and presence of peristalsis (9). As for injuries due to ligation and other basic injuries, stenting should be preferred to avoid potential stenosis and leaks $(10,11)$. Stents should be in place for 2-6 weeks depending on the condition of the patient (12). In complete lacerations of the ureter suturing in addition to stenting, as we did in our case, would be a more favorable method (5).

There also exist various treatment options depending on the location of ureteral injuries. The most commonly injured location is the distal one third of the ureter $(4,6)$. End-to-end anastomosis (ureteroureterostomy) may be performed in injuries at a distance of 3-4 $\mathrm{cm}$ to the ureterovesical junction. In injuries, which are localized closer to the ureterovesical junction, on the other hand, the best option is ureteroneocystostomy (10). Psoas hitch $(6-8 \mathrm{~cm})$ or boari flap $(11-15 \mathrm{~cm})$ methods may be applied to achieve more length in patients who cannot be treated with ureteroneocystostomy alone. In mid-ureter injuries, end-to-end anastomosis (ureteroureterostomy) should be tried at first. If the injury is severe and there is no possibility of performing the repair without tightening, then, psoas hitch, boari flap or transureteroureterostomy may be applied $(13,14)$. Transureteroureterostomy is performed by anastomosing the injured ureter to the contralateral intact ureter. This should be a method of last resort since an iatrogenic injury is created on the intact ureter. As for upper end injuries, end-to-end anastomosis should be tried at first (13).

Ureteroureterostomy should first be tried in complete or partial ureteral detachments. If ureteroureterostomy is not possible, although rarely used, placement of ileal colonic segment in between may be the first option to follow $(15,16)$. Nephrostomy is often used when primary repair is not possible $(16,17)$. Autotransplantation is the procedure to option for in the absence of the other kidney or in case of impaired renal functions and only if the other options are not favorable (17). Nephrectomy, on the other hand, is an option to be applied quite rarely, and should be preferred only after making sure that the functions of the contralateral kidney are normal.

Our case had ureteral injury that occurred during a gynecological operation and underwent conservative or minimally invasive methods since this injury was not a full-thickness incision. The interesting part of the case was that she had a duplicated ureter. This may, in itself, be the intrinsic reason that misled the surgeon during the gynecological operation to bind the ureter. That's why binding or excising should never be performed unless the surgeon is totally sure about the tissues being bound during any surgical procedure. If it is not possible to be sure, it may be an option to check the presence of vessels or ureters by using a fine needle. If the patient did not have a duplicated collective system, the procedure to follow would have been ureteroneocystostomy and psoas hitch as in the case of distal ureteral injuries.

\section{Conclusion}

latrogenic ureteral injuries constitute a major complication that may be experienced even by experienced surgeons. Ureteral anatomy should be well-recognized by all surgeons from all disciplines who are interested in pelvic surgery. Surgery should be meticulously done by extreme attention. In case of a ureteral injury, treatment planning should be done according to anatomical location and operative experience.

\section{Ethics}

Informed Consent: Consent form was filled out by all participants, Peer-review: Internal peer-reviewed.

\section{Authorship Contributions}

Surgical and Medical Practices: Hakan Türk, Ferruh Zorlu, Concept: Hakan Türk, Batuhan Ergani, Design: Batuhan Ergani, Mustafa Karabıçak, Data Collection or Processing: Batuhan Ergani, Cemal Selçuk İşoğlu, Analysis or Interpretation: Hakan Türk, Ferruh Zorlu, Literature Search: Batuhan Ergani, Hakan Türk, Writing: Batuhan Ergani.

Conflict of Interest: No conflict of interest was declared by the authors. Financial Disclosure: The authors declared that this study has received no financial support.

\section{References}

1. Presti JC Jr, Carroll PR, McAninch JW. Ureteral and renal pelvic injuries from external trauma: diagnosis and management. J Trauma 1989;29:370-374.

2. Siram SM, Gerald SZ, Greene WR, Hughes K, Oyetunji TA, Chrouser K, Cornwell EE 3rd, Chang DC. Ureteral trauma: patterns and mechanisms of injury of an uncommon condition. Am J Surg 2010;199:566-570.

3. Guidelines on Urological Trauma. European Association of Urology Guidelines. 2012.

4. Selzman AA, Spirnak JP. latrogenic ureteral injuries: a 20-year experience in treating 165 injuries. J Urol 1996;155:878-881.

5. De Cicco C. Ret Davalos ML, Van Cleynenbreugel B, Verguts J, Koninckx PR. latrogenic ureteral lesions and repair: a review for gynecologists. J Minim Invasive Gynecol 2007;14:428-435.

6. Delacroix SE, Winters JC. Urinary Tract Injures: Recognition and Management. Clin Colon Rectal Surg 2010;23:104-112.

7. Mischianu D, Bratu O, llie C, Madan V. Notes concerning the peritonitis of urinary aetiology. J Med Life 2008;1:66-71.

8. Titton RL, Gervais DA, Hahn PF, Harisinghani MG, Arellano RS, Mueller PR. Urine leaks and urinomas: diagnosis and imaging-guided intervention. Radiographics 2003;23:1133-1147.

9. Minas V, Gul N, Aust T, Doyle M, Rowlands D. Urinary tract injuries in laparoscopic gynaecological surgery; prevention, recognition and management. TOG 2014;16:19-28.

10. Ureteral Trauma Treatment \& Management Richard A Santucci, MD, FACS; Chief Editor: Schwartz BF. Updated: 2012 medscape.

11. Shirk GJ, Johns A, Redwine DB. Complications of laparoscopic surgery: How to avoid them and how to repair them. J Minim Invasive Gynecol. 2006;13:352-359; quiz 360-361.

12. Cholkeri-Singh A, Narepalem N, Miller CE. Laparoscopic ureteral injury and repair: case reviews and clinical update. J Minim Invasive Gynecol 2007; 14:356-361.

13. Simmons MN, Gill IS, Fergany AF, Kaouk JH, Desai MM. Technical modifications to laparoscopic Boari flap. Urology 2007;69:175-180.

14. Pais VM, Strandhoy JW, Assimos DG. Upper urinary tract obstruction and trauma. In: Wein AJ (Eds) Campbell-Walsh Urology, 9th, Elsevier, Philadelphia 2007. p1169.

15. Verduyckt FJ, Heesakkers JP, Debruyne FM. Long-term results of ileum interposition for ureteral obstruction. Eur Urol 2002;42:181-187.

16. McAninch Jack W. Injuries to the Genitourinary Tract, Injuries to the Ureter. Smith's General Urology, 17th Edition. 2008.

17. Brandes S, Coburn M, Armenakas N, McAninch J. Diagnosis and management of ureteric injury: an evidence based analysis. BJU Int 2004;94:277-289. 